\title{
Clinical and Demographic Pattern of Chronic Granulomatous Disease (CGD) from a Multicenter Perspective: Malaysia's Experience Over 26 Years
}

Lokman Mohd Noh ( $\nabla$ lokman.m.noh@gmail.com)

Women and Children Hospital https://orcid.org/0000-0002-1036-9333

Amir Hamzah Abdul Latiff

Pantai Hospital Kuala Lumpur

Intan Hakimah Ismail

Universiti Putra Malaysia

Rahim Md Noah

Universiti Kuala Lumpur

Asrul Abdul Wahab

Universiti Kebangsaan Malaysia

Intan Juliana Abd. Hamid

Universiti Sains Malaysia

Adiratna Mat Ripen

Ministry Health,Institute Medical Research

Nasuruddin B Abdulla

International Islamic University Malaysia

Kamarul Azhar Razali

Institute Pediatrics ,Kuala Lumpur

Norzila Mohamed Zainudin

Institute Pediatrics ,Kuala Lumpur

Florence Bakon

Universiti Malaysia Sarawak

Kok Juan Long

General Hospital Sarawak

Adli Ali

Universiti Kebangsaan Malaysia

Bilkis Banu S Abd Aziz

Universiti Kebangsaan Malaysia

Hasniah Abdul Latif

Universiti Kebangsaan Malaysia

Siti Mardhiana Mohamad

Universiti Sains Malaysia

Zarina T Zainudeen

Universiti Sains Malaysia

Ilie Fadzilah Hashim

Universiti Sains Malaysia

lean Hamzah Sendut

Gleaneagle Hospital ,Kuala Lumpur

Thiyagar Nadarajaw

Sultanah Baiyah Hospital ,Alor Star ,Kedah

Faizah Mohamed Jamil

Hospital Serdang

David CE Ng

Tuanku Jaafar Hospital,Seremban

Mohd Azri Zainal Abidin

Universiti Putra Malaysia Serdang

Research

Keywords: Chronic Granulomatous Disease, Malaysia, clinical, demographic pattern, Chromobacterium violaceum, CD4+ lymphopenia 
Posted Date: January 5th, 2021

DOl: https://doi.org/10.21203/rs.3.rs-138279/v1

License: @ (i) This work is licensed under a Creative Commons Attribution 4.0 International License. Read Full License 


\section{Abstract}

Background:

A retrospective review of clinical manifestations and demographic pattern of patients diagnosed as chronic granulomatous disease (CGD) from 7 hospitals in Malaysia.

\section{Methods:}

Data from the Malaysia Primary Immunodeficiency Network (MyPIN) with cases of CGD diagnosed from 1991 until 2016 were collated and analysed.

\section{Results:}

Twenty patients were diagnosed as CGD. Males $(\mathrm{N}=13,65 \%)$ outnumber females $(\mathrm{N}=7,35 \%)$. The mean age of diagnosis was 3.7 years. There was a positive family history in $40 \%$. Abscess was the main presenting feature in 16 patients (80\%) with one involving the brain (brain abscess). Pneumonia occurred in 10 (50\%) with one (1) with complicated bronchiectasis. Catalase-positive bacteria were the most commonly isolated pathogen with Chromobacterium violaceum (C violaceum) predominating, $\mathrm{N}=5$ (25\%) with consequent high mortality, $\mathrm{N}=4$ ( $80 \%)$. CGD is commonest amongst the Malays (65\%) followed by the Chinese (15.0\%), Indians (10.0\%) and natives of Borneo (10.0\%) reflective of the ethnic composition of the country.

\section{Conclusion:}

This study has shown CGD occurs in the major ethnic groups of Malaysia. To the best of our knowledge, this is the earliest and the largest series of chronic granulomatous disease in South East Asia (SE Asia) which may be reflective of similar clinical pattern in the region. Chromobacterium violaceum infection is associated with a higher mortality in CGD patients in Malaysia. All the CGDs with (C violaceum) infection in this patient series displayed CD4+ (T helper) lymphopenia. We recorded rare clinical manifestation of CGD viz. brain abscess and bronchiectasis.

\section{Background}

Chronic granulomatous disease (CGD) is a genetic disorder resulting from the defect of the enzyme NADPH oxidase. It is responsible for the production of the reactive oxygen species (ROS) by the phagocytes to kill the engulfed pathogen. Defects of this enzyme predispose the susceptible individual to infection mainly by catalase-positive organisms. The mode of inheritance may be further classified into X-linked inheritance (mutation in CYBB gene) and autosomal recessive inheritance (mutation in either CYBA, CYBC1, NCF1, NCF2 and NCF4 genes) [1].

The prevalence of the disease is not well described in many developing countries. A study in the United States (US) estimated the incidence of CGD is between 1 in 200,000 to 1 in 250,000 live births [2]. A systematic review on published primary immunodeficiency disease (PID) in Malaysia showed that CGD was the third most common reported form of PID, which is comparable with Singaporean PID cohort [3]. Chronic granulomatous disease cases in Malaysia were first reported in 1994 that was diagnosed in two unrelated boys [4] based on nitroblue tetrazolium dye test (NBT) and chemiluminescence assay (CA) which would have been the earliest patient reported from South East Asia (SE Asia). Few countries in SE Asia (Malaysia, Singapore and Thailand) have published reports of case series of PID which included CGD [3-7]. This report would be the earliest patient series in SE Asia, revealing some inherent differences in the clinical and demographic patterns from the Europe, America or Asia $(8,9)$

\section{Methods}

Malaysia Primary Immunodeficiency Network (MyPIN) is a collaborative network of clinical immunologists, immunopathologists, scientists and general pediatrician/physicians managing primary immunodeficiency patients in both government and academic institutions. Patients referred for recurrent infections with a diagnosis of primary immunodeficiency seen in seven hospitals in Malaysia between 1986-2016, were entered into data sheets by the corresponding author from the beginning. In the absence of a National centralized registry for the country this is the most optimal system of record to ensure PID (primary immunodeficiency) data is preserved. All clinical and immunological data of patients with diagnosis of chronic granulomatous disease were retrieved and analyzed. The diagnosis of CGD was based on clinical features and abnormality of phagocytic function, inability to generate reactive oxygen species [10]. Only 20 could be retrieved with phagocytic function assay that include either NBT and/or CA and/or dihydrorhodamine 123 (DHR) assay in the participating immunology laboratories. NBT and/or CA were the only assays that could be done up to 2010, subsequent diagnostic test included DHR assay started in Advanced Medical and Dental Institute (AMDI), USM, Penang Malaysia in 2010 (11). Four patients had mutational assays done, (NCF1 and CYBB). Both NBT and CA were done in 4, chemiluminescence assay in 19 and DHR 123 in 4 patients.

\section{Nitroblue Tetrazolium (NBT) Test}

Briefly the NBT, a simplified version of assessing cellular oxidative metabolism, was performed according to the modified method introduced by Noah RM et al using phorbol myristate acetate (PMA) as the activating agent [12]. After incubating the neutrophils with or without PMA, the cells were fixed and stained. Neutrophils showing blue-colored formazan deposits were recorded as PMA stimulated positive cells. The percentage of stimulated neutrophils from the patients was then calculated with reference to the normal controls in order to report as the degree of depression in the oxidative stress of the cells.

\section{Chemiluminescence Assay (CA)}

To increase the accuracy in evaluating phagocytic function of neutrophils, chemiluminescence assay was used. The assay which measured the ability of neutrophils to undergo the respiratory burst gave better comparative differences between neutrophils of patients and normal control in generating oxygen-free 
radicals. Neutrophil suspension mixed with PMA as the stimulant along with luminol (a light amplifier) was placed in the light-proof chamber of the luminometer (LKB1250/Glomax 20/20). The resulting light output in millivolts (mV) was continuously recorded at 10 seconds intervals. The maximum peak readings of chemiluminescence from both patients and normal controls were recorded to calculate the percentage depression of neutrophil function

\section{Dihydrorhodamine (DHR) Test}

DHR samples were then analyzed by using BD FACSCanto ${ }^{T M}$ II. Ten thousand viable granulocytes determined by forward and side scatterplot were collected, and FL2 (585nm) was analyzed. A sample from healthy subject was used as a positive control for each assay. The percentages of cells having produced reactive oxygen radicals were then analyzed as well as the stimulation index (SI) was calculated as the ratio of geometric mean channel fluorescence intensity of PMA-stimulated and unstimulated granulocytes.

\section{Genetic Test}

Genetic tests were not universally available for patients in Malaysia. Only 4 were performed in this cohort and was mainly performed as a research activity, with most of the earlier analysis sent to centers overseas.

\section{Results}

\section{Demography of patients}

Twenty patients were diagnosed with CGD either by functional assays of the phagocyte function that included 13 males and 7 females. Genetic mutational assays were available for four patients, (NCF1 = 2, CYBB =2). However, defect in p47phox protein expression was documented in 6 patients, which were suggestive of autosomal recessive CGD (NCF1 gene mutation).

The mean age onset of symptoms was $2.16( \pm 3.13)$ years old The patients were diagnosed at the age between 0.3 to 12 years, with a mean age of diagnosis of $3.7( \pm 3.95)$ years old. Ethnic distribution showed Malays $(N=13,65 \%)$ was the predominant race, followed by Chinese $15.0 \%(N=3)$, Indians $10.0 \%(N=2)$ and Natives of Borneo $10.0 \%(\mathrm{~N}=2)$. It is remarkable that $5(25 \%)$ of CGD reside in a state of Sarawak, East Malaysia with a population that constitute only $9 \%$ of total Malaysia's population. Family history of early death for possible of primary immunodeficiency diseases in first degree relative was obtained in 8 patients (40\%). Consanguinity was noted in two patients (10.0\%). Table 1 represents the clinical and demographic presentations of the patients with CGD in Malaysia. 
Table 1

Clnical and demographic characteristics of CGD patients in Malaysia 1991-2016.

\begin{tabular}{|c|c|c|c|c|c|c|c|c|c|c|c|c|}
\hline Patient & Gender & Ethnic & $\begin{array}{l}\text { Age(y) } \\
\text { onset. }\end{array}$ & $\begin{array}{l}\text { Age } \\
\text { (y) } \\
\text { diagn. }\end{array}$ & $\begin{array}{l}\text { E Sib } \\
\text { death }\end{array}$ & $\begin{array}{l}\text { Clinical } \\
\text { features }\end{array}$ & Organism & Outcome & $\begin{array}{l}\text { Neutrophi } \\
\text { defect }\end{array}$ & $\begin{array}{l}\text { DHR } \\
a b n\end{array}$ & $\begin{array}{l}\text { Gene } \\
\text { mutatiojn }\end{array}$ & $\begin{array}{l}\text { Prot } \\
\text { abn }\end{array}$ \\
\hline P01 & $\mathrm{F}$ & $M$ & 3 & 7 & $\mathrm{Y}$ & $\begin{array}{l}\text { Abscess skin, } \\
\text { eczema, } \\
\text { septicemia , } \\
\text { retinitis } \\
\text { pigmentosa }\end{array}$ & $\begin{array}{l}\mathrm{N} \text { menigitides, } \mathrm{C} \\
\text { violaceum }\end{array}$ & alive & $\begin{array}{l}\text { CA } \\
\text { NBT }\end{array}$ & nd & NCF1 & $\begin{array}{l}\text { p47 } \\
\text { pho: }\end{array}$ \\
\hline P02 & M & $M$ & na & 1.3 & $Y$ & $\begin{array}{l}\text { Abscess skin } \\
\text { post } \\
\text { vaccination( } \\
\text { thigh ), } \\
\text { cellulitis, } \\
\text { pneumonia, } \\
\text { lymphadenitis, } \\
\text { septicemia, } \\
\text { cholecystitis }\end{array}$ & C violaceum & died & $\begin{array}{l}\text { CA } \\
\text { NBT }\end{array}$ & nd & nd & nd \\
\hline P03 & M & C & 11 & 11 & $\mathrm{Y}$ & pneumonia & norcardia & alive & $\mathrm{CA}$ & nd & nd & $\begin{array}{l}\text { p47 } \\
\text { pho: }\end{array}$ \\
\hline P04 & $\mathrm{F}$ & C & na & 5 & $Y$ & $\begin{array}{l}\text { Recurrent. } \\
\text { lymphadenitis( } \\
\text { cervical ) }\end{array}$ & nil & loss FU & $\mathrm{CA}$ & nd & nd & $\begin{array}{l}\text { p47 } \\
\text { pho: }\end{array}$ \\
\hline P05 & $M$ & $M$ & na & 0.4 & $Y$ & $\begin{array}{l}\text { Abscess (skin , } \\
\text { Liver), } \\
\text { jaundice }\end{array}$ & Staph, E Coli & died & $\begin{array}{l}\text { CA } \\
\text { NBT }\end{array}$ & nd & nd & nd \\
\hline P06 & M & $M$ & na & 0.9 & $\mathbf{Y}$ & $\begin{array}{l}\text { Abscess skin, } \\
\text { pneumonia, } \\
\text { septicemia, } \\
\text { hepatomegaly } \\
\text {,splenomegaly }\end{array}$ & C violaceum & died & $\mathrm{CA}$ & nd & nd & nd \\
\hline P07 & $\mathrm{F}$ & $M$ & na & 0.6 & $\mathbf{n}$ & $\begin{array}{l}\text { A bnormal } \\
\text { facies, } \\
\text { abscess skin , } \\
\text { hepatomegaly } \\
\text {,splenomegaly }\end{array}$ & nil & loss FU & $\mathrm{CA}$ & nd & nd & nd \\
\hline P08 & M & I & 3.7 & 5 & $\mathrm{n}$ & Abscess skin & na & alive & $\mathrm{CA}$ & nd & nd & nd \\
\hline P09 & $\mathrm{F}$ & $M$ & 0.1 & 0.3 & $\mathbf{n}$ & $\begin{array}{l}\text { Abscess scalp } \\
\text {, oral thrush, }\end{array}$ & candida & loss FU & $\mathrm{CA}$ & nd & nd & nd \\
\hline P10 & $\mathrm{F}$ & $M$ & na & 0.9 & na & $\begin{array}{l}\text { Abscess skin } \\
\text { gluteal region }\end{array}$ & na & loss FU & $\mathrm{CA}$ & nd & nd & nd \\
\hline P11 & $\mathrm{F}$ & $M$ & 0.3 & 1 & na & Pneumonia & na & oss FU & $\mathrm{CA}$ & nd & nd & nd \\
\hline P12 & $M$ & NB & 0.3 & 2 & na & $\begin{array}{l}\text { Abscess( (iver } \\
\text {,spleen), } \\
\text { pneumonia }\end{array}$ & $\begin{array}{l}\text { B peudomallei } \\
\text { (titres) }\end{array}$ & $\begin{array}{l}\text { Alive } \\
\text { HSCT }\end{array}$ & $\mathrm{CA}$ & nd & nd & $\begin{array}{l}\text { p47 } \\
\text { pho: }\end{array}$ \\
\hline P13 & $M$ & I & 3 & 12 & $\mathrm{n}$ & $\begin{array}{l}\text { Abscess skin } \\
\text { submental, } \\
\text { inguianal , } \\
\text { recurrent eye } \\
\text { infections }\end{array}$ & na & loss FU & nd & + & nd & $\begin{array}{l}\mathrm{p} 47 \\
\text { pho: }\end{array}$ \\
\hline P14 & $M$ & $M$ & 5 & 5 & na & $\begin{array}{l}\text { Abscess brain } \\
\text {, gangrenous } \\
\text { toe, } \\
\text { hepatomegaly } \\
\text {,splenomegaly }\end{array}$ & C violaceum & died & $\mathrm{CA}$ & nd & NCF1 & $\begin{array}{l}\text { p47 } \\
\text { pho: }\end{array}$ \\
\hline P15 & $\mathrm{F}$ & $M$ & 0.6 & 4.5 & $\mathbf{n}$ & $\begin{array}{l}\text { Abscess } \\
\text { (periosteum, } \\
\text { spleen), } \\
\text { arthritis }\end{array}$ & na & loss FU & $\mathrm{CA}$ & nd & nd & nd \\
\hline P16 & M & NB & 0.67 & 1.9 & $\mathbf{n}$ & $\begin{array}{l}\text { Abscess spleen } \\
\text {,pneumonia, } \\
\text { hepatomegaly } \\
\text {,splenomegaly }\end{array}$ & RSV, mycoplasma & alive & $\mathrm{CA}$ & nd & nd & nd \\
\hline P17 & $M$ & $M$ & 0.08 & 1.6 & $Y$ & $\begin{array}{l}\text { Abscess } \\
\text { speen , } \\
\text { pneumonia, }\end{array}$ & nil & alive & $\mathrm{CA}$ & + & CYBB & nd \\
\hline
\end{tabular}




\begin{tabular}{|c|c|c|c|c|c|c|c|c|c|c|c|c|}
\hline & & & & & & $\begin{array}{l}\text { disseminated } \\
\text { TB }\end{array}$ & & & & & & \\
\hline P18 & $M$ & $\mathrm{C}$ & 0.25 & 0.9 & $\mathrm{n}$ & $\begin{array}{l}\text { Lymphadentis } \\
\text { TB, } \\
\text { pneumonia, } \\
\text { meningitis, } \\
\text { meliodosis } \\
\text { hepatomegaly } \\
\text { splenomegaly }\end{array}$ & $\begin{array}{l}\text { Klebsiella } \\
\text { sp.Staph areus, } \\
\text { B } \\
\text { pseudomallei(titre) }\end{array}$ & alive & $\mathrm{CA}$ & + & CYBB & nd \\
\hline P19 & $M$ & $M$ & na & 12 & $Y$ & $\begin{array}{l}\text { Absccess skin } \\
\text { 'bronchiectasis }\end{array}$ & na & loss FU & CA & + & nd & nd \\
\hline P20 & $M$ & M & 0.08 & 0.6 & $\mathrm{n}$ & $\begin{array}{l}\text { Abscess skin, } \\
\text { pneumonia, } \\
\text { osteomyelitis, } \\
\text { hepatomegaly } \\
\text {,splenomegaly }\end{array}$ & $\begin{array}{l}\text { Kleibsella, C } \\
\text { violaceum, } \\
\text { E coli. }\end{array}$ & died. & $\mathrm{CA}$ & + & nd & nd \\
\hline
\end{tabular}

Legend: E sib death (early sibling death) yes(y) ,no(n) , na (not available);

CA . Chemiluminesc. Assay , + defect present. , nd not done

Ethnic groups : M (Malay) C (Chinese) ,I (Indian) , NB (North Borneo indigenous group); Age in Years ;

Outcome.Loss FU(loss to follow up)

\section{Clinical manifestations and types of infections}

The most common clinical presentation of the patients was abscesses, $80 \%(N=16)$ ( kin $=10$, spleen $=3$, liver $=3$, bone $=1$, brain $=1$, muscle $=1)$ followed by pneumonia $50 \%(\mathrm{~N}=10)$ with one complicating as bronchiectasis. Hepatosplenomegaly $(30 \%)$ and lymphadenitis $(15 \%)$ were the next common findings. Other sites of infections were listed in Table 2. Mycobacterial tuberculosis infection was diagnosed based on clinical grounds.

Table 2

Infections manifestation of CGD patients from Malaysia

\begin{tabular}{|ll|}
\hline Site of Infections & Number of patients (\%) \\
\hline Abscess & $16(80)$ \\
$\cdot$ Skin & 10 \\
$\cdot$ - Liver & 3 \\
$\cdot$ Bone & 3 \\
$\cdot$ Brain & 1 \\
$\cdot$ Muscle & 1 \\
\hline Lung infections (pneumonia/abscess) & $10(50)$ \\
\hline Hepatosplenomegaly & $6(30)$ \\
\hline Septicemia & $3(15)$ \\
Meningitis & $1(5)$ \\
\hline Lymphadenitis & $3(15)$ \\
\hline Eye infection & $1(5)$ \\
\hline Retinitis pigmentosa \& discoid lupus & $1(5)$ \\
\hline Osteomyelitis & $1(5)$ \\
Arthritis & $1(5)$ \\
\hline Oral candidiasis & $2(5)$ \\
\hline
\end{tabular}

\section{Microbiological and Immunological Profiles}

The microbiological profile of the patients was predominantly of the catalase-positive bacteria as shown in Table 3. Chromobacterium violaceum were isolated from 5 (25\%) patients. Melioidosis was diagnosed in 2 children based on high titers to Burkholderia pseudomallei. Staphylococcus spp. was isolated in 2 patients (one with Staphylococcus aureus and one with Staphylococcus epidermidis) from skin abscesses specimens. Bacterial infections ( $\mathrm{N}=13$ ) predominated over fungal infections $(\mathrm{N}=3)$. 
Table 3

Types of microorganism in CGD patients from

\begin{tabular}{|ll|}
\hline \multicolumn{2}{l}{ Malaysia } \\
\hline Organism & $\begin{array}{l}\text { Frequency } \\
\mathbf{n}(\%)\end{array}$ \\
\hline Chromobacterium violaceum & $5(25)$ \\
\hline Burkholderia pseudomallei (titre) & $2(10)$ \\
\hline Staphylococcus spp. & $2(10)$ \\
\hline Klebsiella & $2(10)$ \\
\hline Candida* & $2(10)$ \\
\hline Nocardia & $1(5)$ \\
\hline RSV & $1(5)$ \\
\hline Neisseria meningitidis & $1(5)$ \\
\hline E coli & $1(5)$ \\
\hline Mycoplasma & $1(5)$ \\
\hline *Oral candidiasis in both patient & \\
\hline
\end{tabular}

Immunological parameters: see Table 4.

Table 4

Proportion(\%) of CGD with high or low Immune parameters in Malaysian patients with CGD

\begin{tabular}{|c|c|c|c|}
\hline \multirow[t]{2}{*}{ Immune parameters } & High levels* & Normal levels & Low levels** \\
\hline & $\mathbf{N}(\%)$ & $N(\%)$ & $\mathbf{N}(\%)$ \\
\hline \multicolumn{4}{|l|}{ Lymphocyte subsets } \\
\hline CD3+/T cells $(\mathrm{N}=15)$ & $7(46.6 \%)$ & $7(46.6)$ & $1(6.7 \%)$ \\
\hline CD4+/Th cells $(\mathrm{N}=11$ & $3(27.3 \%$ & $4(36.4)$ & 4. $(36.4 \%)$ \\
\hline CD8 /Tc cells $(N=11)$ & $4(36.4 \%)$ & $5(45.5)$ & 2(18.2) \\
\hline $\mathrm{B}$ cell $(\mathrm{N}=15)$ & $3(20 \%)$ & $8(53.3 \%)$ & $4(26.6 \%)$ \\
\hline \multicolumn{4}{|l|}{ Serum Immunoglobulins } \\
\hline $\lg G(N=15$ & $11(73)$ & $3(20)$ & $1(6)$ \\
\hline $\lg A(N=14)$ & $12(86)$ & $2(14.2)$ & 0 \\
\hline $\lg M(N=15)$ & $8(53)$ & $7(47)$ & 0 \\
\hline \multicolumn{4}{|c|}{ *Above normal range for age matched healthy children } \\
\hline \multicolumn{4}{|c|}{${ }^{\star}$ Below normal range for age matched healthy children } \\
\hline \multicolumn{4}{|l|}{ notes } \\
\hline \multicolumn{4}{|c|}{ Normal \& high level IgG. 14/15 (93.3\%) CD3 + cells 14/15(93.3\%) } \\
\hline \multicolumn{4}{|c|}{ Normal \& high level IgA. 14/14. (100\%) CD4 + cells 7/11 (63.6\%) } \\
\hline Normal & 10.1700 & 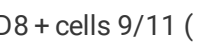 & $1.8 \%$ \\
\hline
\end{tabular}

The serum immunoglobulin showed hypergammaglobulinemia with elevated IgG and $\operatorname{lgA}$ at $73 \%$ and $86 \%$ respectively, while elevated IgM stood at $53 \%$. Elevated lymphocyte subsets cells counts were also observed, Forty six (46) \% of CGD had elevated T/CD3 + lymphocyte counts ,less with Th/CD4 + and Tc /CD $8+$ cells at $27 \%$ and $36 \%$ respectively; Only $20 \%$ of B cells were elevated. CD $4+$ lymphopenia was seen $36.4 \%$ with CD3 and CD 8 at $6.7 \%$ and $18.2 \%$ of CGD patients respectively. Low Immunoglobulin levels were not affected to such a degree with ranges between $0-6 \%$ only. Interesting all the 4 (100\%) CGD patients with CD4 lymphopenia had been infected with $C$ violaceum.

\section{Management and outcome of the patients}

Of the patients that could be followed up, 5 (25\%) died, with 4 patients displayed $C$ violaceum infection. It appeared that $C$ violaceum in $C G D$ was associated with high mortality rate ( $80 \%)$. Most of the patients received trimethoprim-sulfamethoxazole as an antibiotic of choice for prophylaxis. None received IFN 
(interferon) gamma therapy as it was not readily available locally. One patient (P12) received allogeneic hematopoietic stem cell transplantation and is still alive 12 years later [13].

\section{Discussion}

The earliest published report of CGD in Malaysia as case reports was in 1994 compared to India in 1999, Taiwan in 2000 [[4, 14, 15].]. There was another report of CGD in Malaysia in 2012 [16]. Herein we report 20 cases of CGD from 7 hospitals located both Peninsular and East Malaysia. As with most South East Asian countries, facilities and resources for PID care in Malaysia is limited; mutational analysis was not available locally until the last decade, samples had to be sent overseas.

To the best of our knowledge our report as a CGD patient series is the earliest and the largest from SE Asia; the other large series from Thailand is a PID series of 67 patients which included 6 CGD patients [7]. The mean age of diagnosis for our patients was 3.7 years, much later than Sri Lanka, (1.6 years) and China, (2.24 years) but earlier than India, (4.6 years) $[8,9,17]$.

Chronic granulomatous disease occurs more commonly in males and with X-linked mode of inheritance as seen in two large studies from Europe and USA where males predominate with the former at $81 \%$ (351 out of 429) and the latter at 70.5\% (259 out of 368 patients), respectively [2, 19]. Similar occurrence was seen in France (88 out of 97 patients, 90.7\%) [18]. Predominant mode of autosomal recessive inheritance is seen in reports from India, Iran, Turkey, Israel and Saudi Arabia [9, 21-24]. It is noteworthy that a study done in a province in Saudi Arabia reported that all their patients are autosomal recessive with a point prevalence of 6.4 per 100,000, the highest report up to 2009 in the literature [24]. Positive family history is seen in $40 \%$ of the Malaysian series which is higher in large report from China $28 \%$ or Italy $35 \%[17,25]$. We could not conclude that there is a preponderance for autosomal recessive CGD over X-linked CGD in our cohort in view of limited genetic mutational analysis performed. Interestingly 4 of 6 (66\%) with p47 Phox, a marker of AR CGD defect were males. Further data on the mutational analysis will be needed to confirm if indeed there is a preponderance of AR CGD over XL CGD in Malaysia

Abscesses are the most common presentation, unlike most other series where pneumonia is the commonest $[2,18,20,22]$. Pneumonia constitutes only $50 \%$ in our series making it the second most common presentation. One of the Malaysian patients had bronchiectasis as a sequela. Bronchiectasis is not a common finding amongst those with lung infections [21]. Brain abscess, a very uncommon presentation, is present in our series. Such presentation has been reported in another series [2, 23]. Lymphadenitis was the most common clinical presentations in some CGD series. However, in the Malaysian cohort it is the third common presentation $[8,19,21,24]$. Hepatosplenomegaly is also one of the common physical findings $(30 \%)$.

In term of infectious organism, patients with CGD are prone to catalase-positive bacteria including $C$ violaceum. It is a gram-negative facultative anaerobe which is catalase positive dominating a variety of ecosystem in tropics and sub-tropical regions. It is a rare infection in human with less than 200 cases reported in the literature. [27, 28]. However, they can have a fulminating presentation with a high mortality [29]. Infection in human was first documented in Malaysia (1927) later Singapore, Vietnam, Thailand, Sri Lanka, Taiwan, Hong Kong, India, Australia, Southeast region of USA, and Latin America (Brazil /Argentina) $[28,31]$

Earlier report indicated C Violalceum infection in CGD patients as being rare with only one of 368 patients between 1993-1997, US Registry [2]. It is notable Malaysia had 2 reports of C violaceum in CGD patients first in 1994 and a second, later in $2008[4,26]$.

Subsequent literature in the English language (1971-2005) reported more children with invasive $C$ violaceum infection $(n=25)$ with $36 \%$ afflicted with CGD

[30]. However, when considering proportion of CGD patients with C Vioalceum infection, it was $42.9 \%$. and $25 \%$ for Thailand and Malaysia respectively [7, 27]. In the present study CGD patients are likely to succumb to $C$ violaceum infection.

Mortality for all $C$ violaceum varies from $53-80 \%$, with higher risk in disseminated form of infection [29]. it is lower for Australia (7.1\%) and Southeast USA (11.1\%). Mortality of CGD with C violaceum infection is low (7\%) in Southeast USA [27,31] as compared to Malaysia at $80 \%$ (present study); interestingly analysis of USA data those 9 grouped as CGD, 6/9 (66.7\%) were not diagnosed as CGD at presentation to the hospital [31]

We have within in our present cohort a similar pattern; our 2 patients, P02 \& P14, not known to have CGD on admission to the hospital, were found to have CGD subsequently. Patient P02 the younger male sibling of P1 (female) was relatively healthy well until he played football in a muddy field at age of 17 years, ending with a demise with a Chromobacterium violaceum septicemia from an infected wound on the toe. Another Patient 14 who lived in rural Sarawak, East Malaysia close to a swampy area made demise from Chromobacterium violaceum infection with complicating brain abscess after suffering from an infected toe. Both were later revealed the diagnosis as CGD with disseminated form of infection.

The next common infection was Burkholderia pseudomallei , also waterborne organism presenting as melioidosis. Both of our patients survived with one having undergone HSCT. Other studies reported Staphylococcus spp. as the most common organisms isolated among their CGD patient [18, 19]. However Staphylococcus spp. infection constitutes $10 \%$ of our series. Salmonella spp. was noted as the most common pathogen isolated from CGD patients with septicemia [ 2]; however not in our cohort.

Several studies had indicated fungal infections as the predominant organisms in their CGD patients with Aspergillus spp. the predominant fungi isolated [ 9,22,23]. However, Aspergillus spp. was not isolated in our patient samples. Instead Candida spp. and Nocardia were isolated in our laboratory.

Mycobacterium tuberculosis infection afflicted significant proportion of CGD in Sri Lanka, China and South East Asia [8, 17, 23]. Pulmonary tuberculosis is seen in 77\% of CGD in Sri Lanka and 31.7\% of CGD in Iran [8, 21]. Tuberculosis did not occur as frequently in our series with only 2 (10\%) recorded, each of which had lymphadenitis and the other disseminated form of tuberculosis. Complications of BCG are also frequently encountered. A case series from China 
recorded a high infectious complication from BCG in those with CGD. Of the 45 BCG vaccinated patients, 24 (53\%) resulted with BCG infection, mainly in the region confined to the vaccinated site and 2 with disseminated BCG infection / BCGosis [17]. It is notable that patients with CGD tends to develop severe localized BCG infection rather than disseminated BCG infection. In a review by Bustamante et al on mycobacterial infection in CGD, of the 45 with CGD disease, 29 (64.4\%) had local or regional BCG disease while 16 (35.6\%) others had disseminated BCG disease. [33]

Patients with long standing CGD may develop non-infectious inflammatory complications. Previous studies had indicated various non-infectious inflammatory complications that occurred at different sites of the body. The manifestations included autoimmune manifestations, organ obstruction and granuloma formation. In one study, autoimmune phenomena occurred in about 50\% of their CGD patients and, the manifestations included inflammatory bowel disease, reactive arthritis, idiopathic thrombocytopenia and autoimmune hepatitis [22]. Another study showed that granuloma occurred in $68 \%$ of their patients and the most common site of this granuloma was in the liver [2]. Wolach et al, described gastric outlet obstruction, urinary outlet obstruction and colitis/enteritis as the most common inflammatory complications [23]. Lupus syndrome was also reported in some of the patients [2]. We recorded one patient with retinitis pigmentosa and discoid lupus. Chorioretinitis had been reported in the case series from Israel [23]. We would suggest for the non-infectious inflammatory complications be actively sought out during the serial clinic follow up.

The serum immunoglobulin level is typically hypergammaglobulinemic in CGD [34, 35] which is ascribed to infections by bacteria and fungi [34, 35]. CD3 + lymphocytosis was seen to a lesser degree with none above $47 \%$ in our cohort. However, with low levels, CD4 + lymphopenia was seen $36.4 \%$. Low Immunoglobulin levels are not affected to such degree with ranges between 0-6\% only. Interestingly all the 4 (100\%) CGD patients with low CD4 lymphopenia had $C$ violaceum infection. Studies of T cell immunity in CGD were reported as normal, but idiopathic CD4 lymphopenia has been a relative common finding. [36]. We cannot hypothesize whether $C$ violaceum is the cause of or the effect of CD4 lymphopenia in the Malaysian CGD series. The answer would come from further studies.

Prevention of infectious complications of CGD includes prophylaxis with appropriate antimicrobial agents; prophylaxis which includes trimethoprimsulfamethoxazole at $5 \mathrm{mg} / \mathrm{kg} /$ day (based on TMP component) and itraconazole at $5 \mathrm{mg} / \mathrm{kg} /$ day up to $100 \mathrm{mg}$ daily (if body weight< $50 \mathrm{~kg}$ ), or $200 \mathrm{mg}$ daily if body weight $>50 \mathrm{~kg}$ [37]. Interferon gamma (IFNY) are not available in Malaysia. The frequency of allogeneic hematopoietic stem cell transplantation (HSCT) as curative treatment options for CGD has increased since 2006 worldwide. The largest retrospective review on the outcome of hematopoietic stem cell transplantation on 712 patients with CGD demonstrated good survival outcome, low incidence of graft failure and mortality in all ages [38]. The allogenic hematopoietic stem cell transplantation in the Malaysian government healthcare service has just recently started for primary immunodeficiency diseases in Malaysia and a patient (P12) from this cohort was successfully underwent HSCT with matched sibling donor [13].

Overall survival of CGD is $90 \%$ stretched well to adulthood [26]. Others quoted $81 \%$ with long term survival [18]. However, the survival rate is lower in developing countries. The mortality of the patients that we could follow up was $25 \%$ which was lower than India (35\%) [7], Sri Lanka $38 \%$ [6], but higher than the European cohort 20\% [14]. [8, 9, 18]. Previous study demonstrated strong association between residual related reactive oxygen intermediates (ROIs) and survival of patients with CGD; where those with little residual production of ROI may fare worse in the severity of illness and survival outcome [39]

\section{Conclusion}

We have shown that CGD is prevalent in Malaysia and that similar prevalence could occur in South East Asia region. Neutrophil function assays, NBT \& chemiluminescence assay for diagnosis bodes well with later more definitive flow cytometry and mutational analysis in our experience. it is still applicable for countries where resources are limited for PID care. Rarer clinical presentation such as brain abscess and bronchiectasis have been observed in mainly in the Borneo portion of Malaysia. Idiopathic CD4 lymphopenia, a relatively common finding in CGD is strongly associated with Chromobacterium violaceum infection with high mortality. It is suggested that assessment for CGD should be warranted when confronted with a previously healthy child with Chromobacterium violaceum sepsis in SE Asia. It is likely that the countries in surrounding region to Malaysia may share similar phenomena.

\section{Declarations}

\section{Ethic Approval and consent to participate}

Ethic approval was obtained from 2 Institutions

a. Research grant (RU) 1001/CIPPT/812036.Universiti Sains Malaysia/USM (11 May 2009)

b. Ministry of Health Malaysia .NMRR-09-284-3887; Ethic \& Research Committee (13 May 2010)

\section{Consent for publication}

Not applicable as this is a retrospective study based on selected aspects of patients' clinical summary (from participating hospitals in Malaysia) transferred to a separate database record kept by the corresponding author Individual case cannot be identified in manuscript. There were no interventional procedures other than is required by attending pediatrician for diagnosis and management.

\section{Availability of data material}

All data generated or analysed in this study and included in this article are available from the corresponding author on a reasonable request .

\section{Competing interest}


The authors have no declared conflicting interest .

\section{Funding}

Research grant (RU) 1001/CIPPT/812036.Universiti Sains Malaysia/USM - 100,000 RM

\section{Authors Contribution}

CONCEPTUALIZATION and design of study, acquisition and analysis of of data, writing of manuscript.

\section{LMN}

AHAL

$\mathrm{IHI}$

RMN

AAW

IJAH

AA

Recruitmen of patients and acquisition of study and data curation

NBA

AMR

ZT Z

NM Z

KAZ

FB

KJL

$\mathrm{T} \mathrm{N}$

FMJ

DN

$\mathrm{IH}$

BBSAA

HAL

MAZA

SMM

IFH

Writing original draft

LMN,

AAW,

AHAL ,

IHI

\section{Acknowledgement}

We would like to thank the Director General of Health Malaysia for his permission to publish this article. We thank all the 7 hospitals involved especially the nursing staffs and doctors. We also like to thank all the participating laboratories. 
The study was approved by the Research Committee and Ethics Research in Human University Sains Malaysia; Ethical issues were addressed as in research grants: USM RU 1001/CIPPT/812036 and

Ethical approval for this study was obtained from the Medical Research and Ethical Committee (MREC) Ministry of Health Malaysia NMRR-09-284-3887.

\section{Conflict of interest}

The authors declare that they have no competing interests.

\section{References}

1. Tangye, S.G., Al-Herz, W., Bousfiha, A. et al.Human Inborn Errors of Immunity: 2019 Update on the Classification from the International Union of Immunological Societies Expert Committee. J Clin Immunol40, 24-64 (2020).

2. Winkelstein JA, Marino MC, Johnston RB, Boyle J, Curnutte J, Gallin JI, et al. Chronic Granulomatous Disease Report on a National Registry of 368 Patients. Medicine. 2000; 79: 155-69

3. Abd Hamid IJ, Azman NA, Gennery AR, Mangantig E, Hashim IF and Zainudeen ZT (2020) Systematic Review of Primary Immunodeficiency Diseases in Malaysia: 1979-2020. Front. Immunol. 11:1923. doi: 10.3389/fimmu.2020.01923

4. Noh LM, Noah RM, Wu LL, Nasuruddin BA, Junaidah E, Ooi CP, et al. Chronic Granulomatous Disease-A Report in Two Malay Families. Singapore Med J. 1994; 35: 505-508.

5. Noh LM, Nasuruddin BA, Abdul Latiff AH, Noah RM, Kamarul Azahar MR, Norzila MZ, et al. Clinical-epidemiological pattern of primary immunodeficiencies in Malaysia 1987-2006: a 20 year experience in four Malaysian Hospitals. Med J Malays. 2013;68(1):13-7.

6. Lim DL, Thong BY, Ho SY, Shek LPC, Lou J, Leong KP, et al. Primary Immunodeficiency Diseases in Singapore-the Last 11 Years. Singapore Med J. 2003 ; 44(11): 579-586

7. Benjasupattanan B, Simasathein T, Vichayanond P,Leungvedchakarn V,Vsitsunthorn N, Pacharn P, Jirapongsannanuruk $O$ et al. Clinical Characteristic and outcome of PID in Thai children: an 18 year experience from a tertiary care centre. J Clin Immunol. 2009; 29: 357-364.

8. Fernando S J A, Faiz N M, Handunneti S M , De Silva AD, Desnayake WMDK, Vickramasinghe ,G D, Silva et al. Preliminary stuy on CGD in Sri Lanka. Allergy Asthma Clin Immunol. 2018;14-37

9. Rawat A, Singh S, Suri D, Gupta A, Saikia B, Minz RW, et al. Chronic Granulomatous Disease: Two Decades of Experience From a Tertiary Care Centre in North West India. J Clin Immunol. 2014; 34: 58-67. DOI 10.1007/s10875-013-9963-5

10. Roos D, Kuijpers TW, Cutnutte JT. Chronic Granulomatous Disease. In: HD Ochs, Cl Edvard Smith, JM Puck. editors . Primary Immunodeficiency Disease. Molecular and Genetic approach. Oxford University Press. 2007.pp.534-540

11. Zainudeen, Z. T., Hashim, I. F. \& Abd Hamid, I. J. (2020). Chronic Granulomatous Disease . Malaysian Journal of Paediatrics and Child Health, 25(2), 2829. Retrieved from https://mpaeds.my/journals/index.php/MJPCH/article/view/17

12. Noah RM, Jais MR,Noh LM.Evaluation of variable parameters in Neutrophil functionusing chemiluminescence assay. Malaysian J Patho 1994; 16(20157160

13. Ismail IH, Jamli FM, Othman IS, Noh LM, Abdul Latiff AH. Malaysia's First Transplanted Case of Chronic Granulomatous Disease: The Journey of Overcoming Obstacles. Children (Basel). 2016 May 17;3(2):9. doi: 10.3390/children3020009. PMID: 27417247; PMCID: PMC4934564.

14. Salaria M, Singh S, Kumar L, Datta U, Sehgal S. Chronic Granulomatous Disease. 2Indian Pediatric 1999; 36(6):594

15. Ma JS, Chen PY, Fu LS, Chi CS, Huang YF, Lin CY, Shieh CC. Chronic Granulomatous disease. A case report J Microbiology Immunology and Infection. 2000,33(2): :118-122

16. Gill HK, Kumar HC ,Dhaliwal JS, Zabidi F, Sendut IH ,Noah RM ,Noh LM ,Latif AHAL ,Murad S . Defining p47 - phox deficient Chronic Granulomatous Disease in a Malay Family. Asian Pac J Allergy . 2012; 30 (4):313

17. Wu. J, Wang WF, Zhang Y, Chen T.Clinical Features and analysis of 48 patients with chronic granulomatous disease in a single centre study from Shanghai China (2005-2015).New studies and literature review. Journal of Immunological Research 2017; (https://doi.org/10.1155/2017/8745254.)

18. Van den Berg JM, van Koppen E, Ahlin A, Belohradsky BH, Bernatowska E, Corbeel L, et al. Chronic Granulomatous Disease: The European Experience. PLoSONE. 2009: 4(4); e5234.

19. Bortoletto P, Lyman K, Camacho A, Fricchione M, Khanolkar A, Katz BZ, et al. Chronic Granulomatous Disease A Large, Single-center US Experience. Pediatr Infect Dis J. 2015; 34: 1110-1114.

20. Magnani A, Brosselin P, Beautè J, de Vergnes N, Mouy R, Debrè M, et al. Inflammatory manifestations in a single-center cohort of patients with chronic granulomatous disease. J Allergy Clin Immunol. 2014; 134(3): 655-662.

21. Movahedi M, Aghamohammadi A, Rezaei N, Shahnavaz N, Jandaghi AB, Farhoudi A, et al. Chronic Granulomatous Disease: A Clinical Survey of 41 Patients from The Iranian Primary Immunodeficiency Registry. Int Arch Allergy immunol. 2004: 134; 253-259. D0I: 10.1159/000078774

22. Köker MY, Camcioglu Y, van Leeuwen K, Kilic SS, Barlan I, Yilmaz M, et al. Clinical, functional and genetic characterization of chronic granulomatous disease in 89 Turkish patients. J Allergy Clin Immunol. 2013; 132:1156-1163. http://dx.doi.org/10.1016/j.jaci.2013.05.039

23. Wolach B, Gavrieli R, de Boer M, van Leeuwen K, Berger-Achituv S, Satuber T, et al. Chronic granulomatous disease: Clinical, functional, molecular, and genetic studies. The Israel experience with 84 patients. American Journal of Hematology. 2017; 92: 28-36. 
24. Suliaman F, Amra N, Sheikh S, Almuhsen S, Alsmadi O. Epidemiology of Chronic Granulomatous Disease of Childhood in Eastern Province, Saudi Arabia. Pediatric Asthma, Allegy, \& Immunology. 2009; 22 (1): 21-26. DOI: 10.1089/pai.2008.0513

25. Martire B, Rondelli R, Soresina A, Pignata C, Brocoletti T, Finocchi A et al. Clinical features, long term follow up, and outcome of a large cohort of patients with chronic granulomatous disease: An Italian Multi Centre Study. Clin Immuno 2008; 126:155-164

26. Sureish M., Choon S.K. \& Tai C.C. Recurrent Chromobacterium violaceum infection in a patient with chronic granulomatous disease. Med J Malaysia 2008; 63:346-7

27. Frawley A ,Powell L, Mcquiston JR ,Gulvik CA ,Beque RE . Necrotisin Pneumonia caused by C violaceum . Report of a rare human pathogen causing disease in an immunodeficienc child.Am. J. Tropical Med. Hyg.2018;9(1):164-167

28. Lee PP,Lau YL. Endemic infection in Se Asia provide new insight. to th phenotypic spectrum of primary immunodeficiency disorder. Asia Pacific J Allergy \& immunology.2013;31:217-26. See 32

29. Bansie R, Harkinson S ,Lachman V ,Lai A. Fat , E .Ramdhani N ,van Laar Jam .A Rare infection in the tropics that is not uncommon in case of CGD . Case Report. Access Microbiology 2019 ;26 jun 2019 . DOI.1009 /acmi.0.000039

30. Sirinavin S, Techasensari C ,Benjaponpitak S ,Pornkul R, Vorachit M . Invasive Chromobacterium violaceum indfection in children : A case report and review.Ped Infect Dis 2005; 24(6): 559-561.

31. Mehrer-Homji et al C violaceum infection in chronic granulomatous disease; a case report a. a review of the literature. JMM Case report 2017:4

32. Lee PW, Lau YL. Endemic infections in S E Asia provide new insights to the phenotypic spectrum of PID in SE Asia. Asia Pacific J Allergy Immunol. 2013; 31:217-26.

33. Bustamante. J, Guzide A, Guillaume V, Ludovic de Beaucoudrey, Ferah G, Ariane C, et. al. BCG-osis and tuberculosis in a child with chronic granulomatous disease, Journal of Allergy and Clinical Immunology, Volume 120, Issue 1, 2007: 32-38, https://doi.org/10.1016/j.jaci.2007.04.034.

34. Steven M Holland. Chronic Granulomatous Disease. Hemato Oncol Clin N Am. 2013; 27:89-99.

35. Janeway CA, Craig J, Davidson M et al. Hypergammaglobulinemia associated with severe recurrent and chronic non-specific infection. Am J Dis Child $1954 ; 88: 388-92$

36. Leiding JW ,Holland SM . Chronic Granulomatous Disease . In : Steihm Immune deficiency . Ed. Kathleen E Sullivan\& E Richard Steihm .Elsevier . 2014. Pp 640

37. Thomsen IP, Smith MA, Holland SM, Creech CB. A Comprehensive Approach to the Management of Children and Adults with Chronic Granulomatous Disease. J Allergy Clin Immunol Pract. 2016 Nov-Dec;4(6):1082-1088. doi: 10.1016/j.jaip.2016.03.021

38. Robert Chiesa, Junfeng Wang, Henric-Jan Blok, Sheree Hazelaar, Benedicte Neven, Despina Moshous, et. al; for the EBMT Inborn Errors Working Party, Hematopoietic cell transplantation in chronic granulomatous disease: a study of 712 children and adults.Blood $2020 ; 136$ (10): $1201-1211$. doi:https://doi.org/10.1182/blood.2020005590

39. Kuhns DB, Alvord WG, Heller T, Feld JJ, Pike KM, Marciano BE, et al. Residual NADPH oxidase and survival in chronic granulomatous dis- ease. N Engl J Med. 2010;363(27):2600-10. DOI:10.1056/NEJMoa1007097 